\title{
Anaerobic oxidation of glycerol by Escherichia coli in an amperometric poised-potential culture system
}

\author{
Rainer Emde, Ann Swain*, and Bernhard Schink \\ Lehrstuhl Mikrobiologie I der Eberhard-Karls-Universität, Auf der Morgenstelle 28, D-7400 Tübingen, Federal Republic of \\ Germany
}

Summary. Anaerobic growth of Escherichia coli was studied with glycerol as electron source and a three-electrode poised-potential system with potassium ferricyanide as mediator. Similar to fumarate, potassium ferricyanide was used as electron acceptor in batch-culture experiments. In experiments with regulated electrodes, glycerol was degraded completely, and an electron flow of 3.0 to $4.0 \mathrm{~mA}$ was obtained. The electron balances were in the range of $98 \%-107 \%$, and a growth rate of $0.095 \mathrm{~h}^{-1}$ was calculated. These results are discussed with respect to the energetics of iron reduction by $E$. coli and by other bacteria.

\section{Introduction}

Direct reduction of artificial electron acceptors (mediators) by free enzymes and intact microbial cells has been used repeatedly in previous years to generate electrical currents in microbial fuel cells (Plotkin et al. 1981; Davis et al. 1983; Tanaka et al. 1983; Delaney et al. 1984; Roller et al. 1984). Dichlorophenol indophenol (Nishikawa et al. 1982), phenazine ethosulphate (Turner et al. 1982), and potassium ferricyanide (Ramsey et al. 1985) have been applied as mediators in various fuel cell and amperometric systems as possible measures of microbial cell densities. With potassium ferricyanide as a soluble and chemically stable mediator, Ramsey et al. (1985) could estimate Escherichia coli cell numbers with a lower detection limit of $5 \times 10^{6}$ cells $\mathrm{ml}^{-1}$. For their experiments, these authors used two- or three-electrode,

\footnotetext{
* Present address: Biotechnology Centre, Cranfield Institute of Technology, Cranfield, Beds, MK43 OAL, UK

Offprint requests to: $\mathbf{R}$. Emde
}

poised-potential amperometric systems. In these systems, potassium ferricyanide was reduced by the bacterial cells and reoxidized at the working electrode.

The present study was initiated to evaluate whether potassium ferricyanide can act as an electron acceptor that could replace fumarate or nitrate during anaerobic growth of E. coli. Glycerol was chosen as substrate for these experiments because $E$. coli is unable to ferment it in the absence of external electron acceptors (Lin 1976). The results indicate that catalytic amounts of this mediator could allow quantitative electron transfer from the growing bacterial cell to a regulated electrode.

\section{Materials and methods}

Bacteria and media. Escherichia coli strain K12 (DSM 498) was obtained from V. Braun, Tübingen, FRG. For all growth experiments, phosphate-buffered mineral medium with $0.7 \mathrm{~g}$ $\mathrm{KH}_{2} \mathrm{PO}_{4}, 4.2 \mathrm{~g} \mathrm{Na} \mathrm{HPO}_{4} \cdot 2 \mathrm{H}_{2} \mathrm{O}, 3.0 \mathrm{~g} \mathrm{NaCl}, 0.5 \mathrm{~g} \mathrm{NH} \mathrm{NH}_{4}$, $0.2 \mathrm{~g} \mathrm{MgCl}_{2} \cdot 6 \mathrm{H}_{2} \mathrm{O}, 0.07 \mathrm{~g} \mathrm{CaSO}_{4} \cdot 2 \mathrm{H}_{2} \mathrm{O}$ and $1.0 \mathrm{~g}$ peptone $/ 1$ was prepared. Phosphates were autoclaved as a separate stock solution. The basal medium was autoclaved and $1 \mathrm{ml}$ trace element solution SL 10 (Widdel et al. 1983) and $1 \mathrm{ml}$ tenfold concentrated 7-vitamin solution (Pfennig 1978) were added per litre of medium. The $\mathrm{pH}$ of the complete medium was 7.2 7.3 .

Culture conditions. Experiments with regulated electrodes were performed in an anoxic three-electrode poised-potential system (modified after Turner et al. 1983; Ramsay et al. 1985) as described in Fig. 1. Before use, the culture vessel, the counter electrode (a platinum wire, diameter $0.5 \mathrm{~mm}$ ), the working electrode (a platinum net of $25 \mathrm{~cm}^{2}$, wire diameter $0.04 \mathrm{~mm}$, 3600 mesh per $\mathrm{cm}^{2}$, mesh diameter $0.125 \mathrm{~mm}$ connected with a platinum wire, diameter $0.5 \mathrm{~mm}$ ), and the reference electrode wire (a silver silver-chloride wire prepared by electrolysis of a silver wire, diameter $0.5 \mathrm{~mm}$, in $1 M \mathrm{HCl}$ ) were autoclaved. Afterwards the Lugin capillary in the working electrode compartment was filled with melted sterile agar solution (3\% agar 


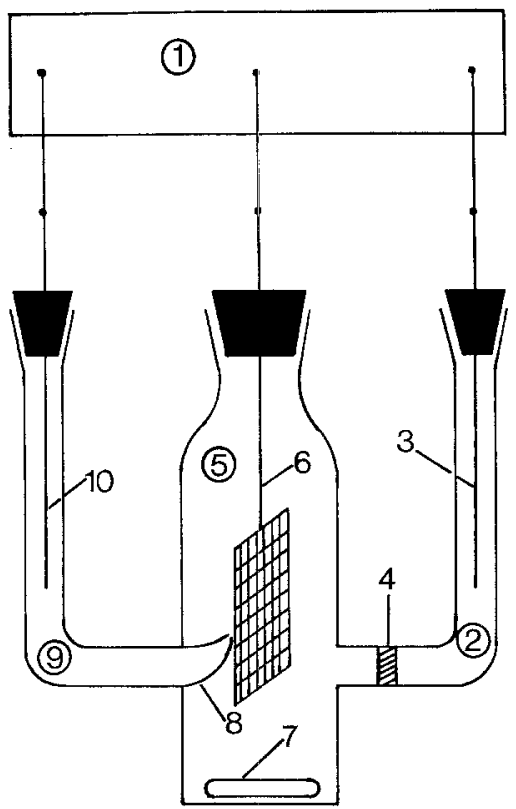

Fig. 1. Three-electrode poised-potential amperometric system: (1) potentiostat, (2) counter electrode compartment, (3) counter electrode, (4) diaphragm, (5) central compartment, (6) working electrode, (7) magnetic stirrer bar, (8) Lugin capillary, (9) reference electrode compartment, (10) reference electrode

$+1 M \mathrm{KCl}$ ). Before use the counter electrode platinum wire and the working electrode platinum net were activated by glowing in a flame. The reference working electrode compartment was filled with $5 \mathrm{ml}$ sterile $1 \mathrm{M} \mathrm{KCl}$ solution. The resulting silver silver-chloride reference electrode had a potential of $+230 \mathrm{mV}$ at $30^{\circ} \mathrm{C}$ as measured against a $0.1 M \mathrm{~K}_{3}\left[\mathrm{Fe}(\mathrm{CN})_{6}\right]$ solution. Medium $(100 \mathrm{ml})$ with mediator, substrate and inoculum was filled into the central compartment, and $5 \mathrm{ml}$ medium was put into the counter electrode compartment. All compartments were closed after sparging with oxygen-free nitrogen. The vessel was incubated in a water bath at $30^{\circ} \mathrm{C}$ with gentle magnetic stirring. The electrodes were connected to a laboratory potentiostat (Type LB $81 \mathrm{M}$, Bank Elektronik, Göttingen, FRG), and the working electrode was poised at a potential of $+280 \mathrm{mV}$ against the silver silver-chloride electrode. With an additional platinum wire in the central compartment, the potential of the growth medium and the electron flow between working and counter electrode could be recorded.

Analytical determinations. Acetate and ethanol were determined as described earlier (Dehning et al. 1989) using a Carlo Erba 6000 Vega Series gas chromatograph (Milano, Italy) equipped with a flame ionization detector and a Merck-Hitachi D-2000 integrator (Tokyo, Japan). Samples ( $3 \mu \mathrm{l})$ were injected directly onto a glass column $(2 \mathrm{~m} \times 2 \mathrm{~mm})$ packed with $60 / 80$ Carbopak C $/ 0.3 \%$ Carbowax $20 \mathrm{M} / 0.1 \% \mathrm{H}_{3} \mathrm{PO}_{4}$ (Supelco, Bellefonte, Pa, USA) at a temperature of $70^{\circ} \mathrm{C}$ (ethanol) or $120^{\circ} \mathrm{C}$ (acetate). For determination of fumarate and succinate (Dehning et al. 1989), $3 \mu$ methylated samples (Metcalfe et al. 1966) were injected onto a capillary column $(15 \mathrm{~m} \times 0.32 \mathrm{~mm})$ with a $0.4 \mu \mathrm{m}$ layer of bonded and cross-linked Carbowax $20 \mathrm{M}$ at a temperature of $140^{\circ} \mathrm{C}$. Hydrogen was assayed as described earlier (Matthies et al. 1989) using a Carlo Erba gas chromatograph with thermal conductivity detector. Gas samples $(300 \mu 1)$ were injected directly onto a steel column $(2 \mathrm{~m} \times 4 \mathrm{~mm})$ packed with a $60 / 80$ mesh molecular sieve $(5 \mathrm{~A}$, Serva, Heidelberg, FRG) at $50^{\circ} \mathrm{C}$. Formate was determined photometrically by a colour reaction (Lang and Lang 1972). Potassium ferricyanide was quantified at $419 \mathrm{~nm}$ in an Uvikon 860 spectrophotometer (Kontron, Zürich, Switzerland). The system was calibrated with $\mathrm{K}_{3}\left[\mathrm{Fe}(\mathrm{CN})_{6}\right]$ at various concentrations. Pure solutions of $\mathrm{K}_{4}\left[\mathrm{Fe}(\mathrm{CN})_{6}\right]$ did not absorb at this wavelength. Lactate and glycerol were determined enzymatically by standard methods (Bergmeyer 1974).

Growth yield determinations. Determinations of cell yields and of metabolic end-products in batch culture were carried out in $60-\mathrm{ml}$ serum bottles. The bottles were filled to an end-volume of $25 \mathrm{ml}$, gassed with oxygen-free nitrogen, and closed with butyl rubber stoppers. Glycerol, fumarate, and potassium ferricyanide were added from freshly prepared stock solutions. Growth yields were calculated via optical densities which were calibrated by direct dry mass determinations in $500 \mathrm{ml}$ bottle cultures. An optical density of $\Delta E_{578}=0.1$ corresponded to $28.1 \pm 3.0 \mathrm{mg}$ dry weight/1. For growth yield determinations in the three-electrode, poised-potential system, samples were taken with a sterile syringe directly from the culture vessel.

Chemicals. All chemicals were of reagent grade quality and obtained from Merck, Darmstadt; Fluka, Neu-Ulm; and Sigma, München, FRG. Enzymes were purchased from Boehringer, Mannheim, FRG.

\section{Results}

Anaerobic growth of $E$. coli was checked in batch culture experiments with glycerol as sole energy source and with fumarate or other electron ac-

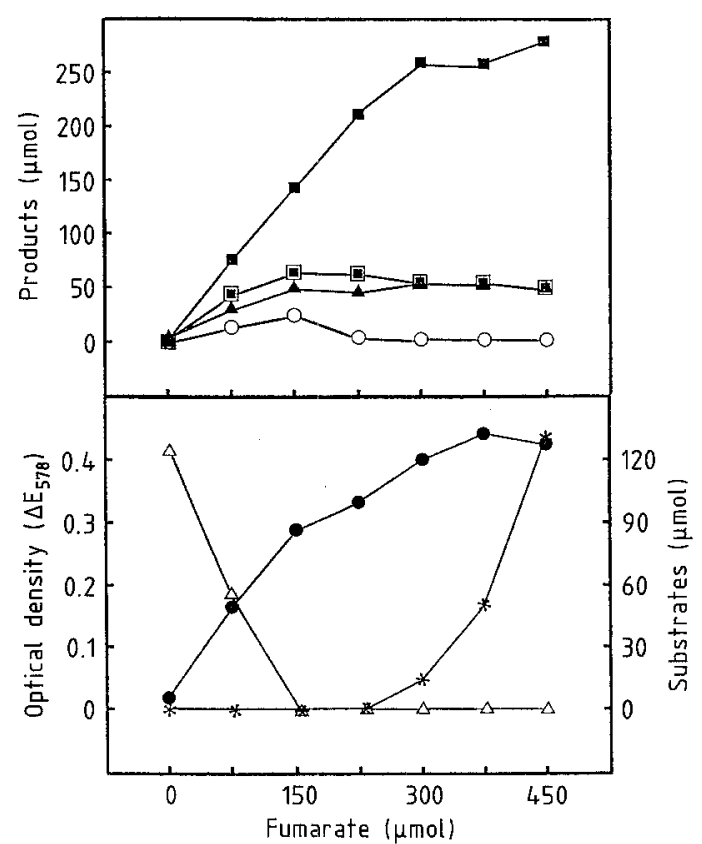

Fig. 2. Growth of Escherichia coli with $5 \mathrm{~m} M$ glycerol and fumarate as electron acceptor at various concentrations in batch culture (linear scale): D, optical density (OD); *, fumarate; $\triangle$, glycerol; $\mathrm{O}, \mathrm{H}_{2} ; \Delta$, acetate; $\square$, ethanol; $\mathbf{\square}$, succinate 
Table 1. Stoichiometry of fermentation by Escherichia coli grown with $5 \mathrm{~m} M$ glycerol $(125 \mu \mathrm{mol})$ and fumarate at various concentrations in batch culture; the amount of formate was always lower than $10.0 \mu \mathrm{mol}$, and the amount of lactate was always lower than $6.25 \mu \mathrm{mol}$

\begin{tabular}{|c|c|c|c|c|c|c|c|c|c|}
\hline \multirow{2}{*}{$\begin{array}{l}\text { Fumarate } \\
\text { provided } \\
(\mu \mathrm{mol})\end{array}$} & \multirow{2}{*}{$\begin{array}{l}\text { Optical } \\
\text { density } \\
\left(\Delta E_{578}\right)\end{array}$} & \multicolumn{2}{|c|}{$\begin{array}{l}\text { Remnant substrates } \\
(\mu \mathrm{mol})\end{array}$} & \multicolumn{4}{|c|}{ Products formed ( $\mu \mathrm{mol})$} & \multirow{2}{*}{$\begin{array}{l}\text { Cell } \\
\text { material } \\
\text { formed }(\mathrm{mg})\end{array}$} & \multirow{2}{*}{$\begin{array}{l}\text { Electrons } \\
\text { recovered } \\
(\%)\end{array}$} \\
\hline & & Gycerol & Fumarate & Acetate & Ethanol & Sucinate & $\mathrm{H}_{2}$ & & \\
\hline$-^{a}$ & 0.015 & $<12.5$ & $<12.5$ & 4.25 & $<2.50$ & $<12.5$ & $<0.78$ & 0.10 & \\
\hline 0 & 0.020 & 119.0 & $<12.5$ & 5.25 & $<2.50$ & $<12.5$ & $<0.78$ & 0.14 & 96.1 \\
\hline 150 & 0.290 & $<12.5$ & $<12.5$ & 47.20 & 61.50 & 143.0 & 24.50 & 2.04 & 99.2 \\
\hline 300 & 0.400 & $<12.5$ & 13.7 & 51.20 & 53.50 & 260.0 & 1.72 & 2.81 & 113.0 \\
\hline 450 & 0.425 & $<12.5$ & 130.0 & 47.00 & 48.00 & 279.0 & 1.25 & 2.99 & 111.0 \\
\hline
\end{tabular}

${ }^{a}$ In this line the results of a control experiment without glycerol are shown

ceptors at various concentrations (Fig. 2; Table 1). Under these conditions, glycerol degradation depended strictly on the electron acceptor concen-

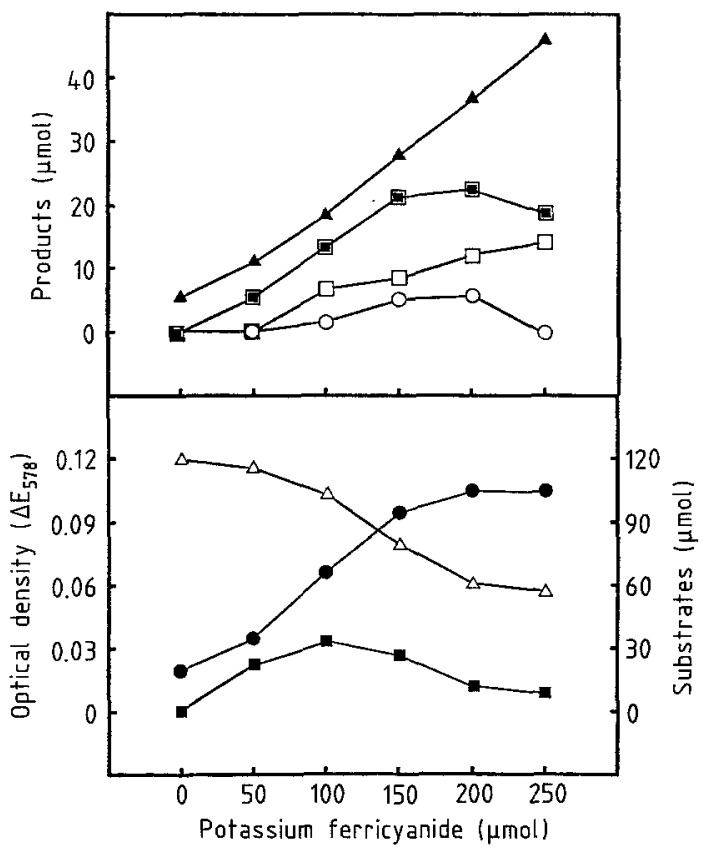

Fig. 3. Growth of $E$. coli with $5 \mathrm{~m} M$ glycerol and potassium ferricyanide at various concentrations in batch culture: $\bullet$, $\mathrm{OD} ; \mathbf{\square}$, potassium ferricyanide; $\triangle$, glycerol; $\mathrm{O}, \mathrm{H}_{2} ; \square$, lactate; $\mathbf{Q}$, ethanol; $\boldsymbol{\Lambda}$, acetate tration. At higher fumarate concentrations, glycerol became the growth-limiting factor. About $100 \%$ of the reduced fumarate could be recovered as succinate in the growth medium. Acetate, ethanol, and $\mathrm{H}_{2}$ were found as fermentation products, but no lactate or formate. Without an electron acceptor, glycerol could not be fermented. The little growth in fumarate-free cultures resulted from peptone fermentation.

Similar results were obtained for anaerobic growth of $E$. coli with $5 \mathrm{~m} M$ glycerol and potassium ferricyanide at various concentrations as shown in Fig. 3 and Table 2. In all cases, ferricyanide was not reduced completely, not even after $120 \mathrm{~h}$ incubation time. The percentage of non-reduced ferricyanide was greater in cultures grown with lower ferricyanide concentrations than in cultures with higher ones. Growth and glycerol degradation depended strictly on ferricyanide reduction. Acetate was the major fermentation product, but also ethanol, lactate, and low amounts of $\mathrm{H}_{2}$ were found. Growth yields with ferricyanide as electron acceptor were lower than with fumarate, implying that ferricyanide reduction is only a one-electron transfer.

Potassium ferricyanide was also used as electron carrier (mediator) in growth experiments with regulated electrodes. However, in reoxida-

Table 2. Stoichiometry of fermentation of $E$. coli grown with $5 \mathrm{~m} M$ glycerol $(125 \mu \mathrm{mol})$ and potassium ferricyanide at various concentrations in batch culture

\begin{tabular}{|c|c|c|c|c|c|c|c|c|c|}
\hline \multirow{2}{*}{$\begin{array}{l}\text { Ferri- } \\
\text { cyanide } \\
\text { provided } \\
(\mu \mathrm{mol})\end{array}$} & \multirow{2}{*}{$\begin{array}{l}\text { Optical } \\
\text { density } \\
\left(\Delta E_{578}\right)\end{array}$} & \multicolumn{2}{|c|}{$\begin{array}{l}\text { Remnant substrates } \\
(\mu \mathrm{mol})\end{array}$} & \multicolumn{4}{|c|}{ Products formed $(\mu \mathrm{mol})$} & \multirow{2}{*}{$\begin{array}{l}\text { Cell } \\
\text { material } \\
\text { formed (mg) }\end{array}$} & \multirow{2}{*}{$\begin{array}{l}\text { Electrons } \\
\text { recovered } \\
(\%)\end{array}$} \\
\hline & & Glycerol & $\begin{array}{l}\text { Ferri- } \\
\text { cyanide }\end{array}$ & Acetate & Ethanol & Lactate & $\mathrm{H}_{2}$ & & \\
\hline 50 & 0.035 & 115.0 & 21.6 & 11.0 & 5.25 & $<6.25$ & $<0.78$ & 0.25 & 101 \\
\hline 150 & 0.095 & 77.7 & 26.7 & 28.0 & 21.20 & 8.20 & 5.00 & 0.67 & 106 \\
\hline 250 & 0.105 & 56.0 & 10.2 & 46.0 & 18.50 & 14.00 & $<0.78$ & 0.74 & 105 \\
\hline
\end{tabular}




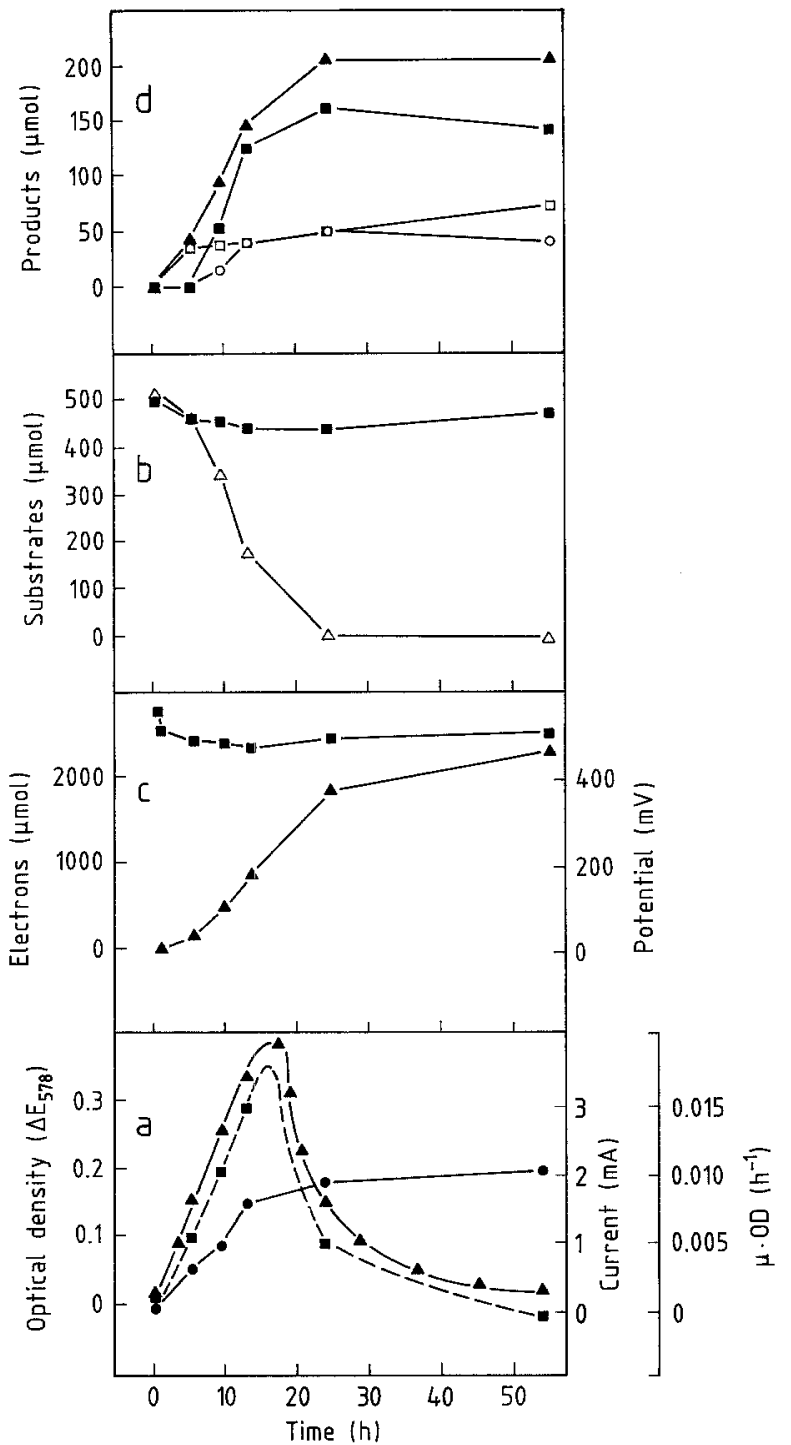

Fig. 4a-d. Growth of $E$. coli with $5 \mathrm{~m} M$ glycerol and $5 \mathrm{~m} M$ potassium ferricyanide in the presence of regulated electrodes. a Optical density $(\bullet)$, current $(\Delta), \mu \times \mathrm{OD}(\boldsymbol{\square})$ (broken line). b Glycerol $(\Delta)$, potassium ferricyanide ( $\boldsymbol{\theta})$. c Amount of electrons transferred to the working electrode $(\mathbf{\Delta})$, potential of the growth medium (a). d Products formed: $\mathrm{H}_{2}(\mathrm{O})$, acetate $(\Delta)$, ethanol (ם), lactate ( $\square$ )

Table 3. Stoichiometry of fermentation of $E$. coli during growth with $5 \mathrm{~m} M$ glycerol $(500 \mu \mathrm{mol})$ and $5 \mathrm{~m} M$ potassium ferricyanide in the presence of regulated electrodes

\begin{tabular}{|c|c|c|c|c|c|c|c|c|c|}
\hline \multirow{2}{*}{$\begin{array}{l}\text { Incubation } \\
\text { time } \\
\text { (h) }\end{array}$} & \multirow{2}{*}{$\begin{array}{l}\text { Optical } \\
\text { density } \\
\left(\Delta E_{578}\right)\end{array}$} & \multirow{2}{*}{$\begin{array}{l}\text { Remnant } \\
\text { glycerol } \\
(\mu \mathrm{mol})\end{array}$} & \multicolumn{4}{|c|}{ Products formed $(\mu \mathrm{mol})$} & \multirow{2}{*}{$\begin{array}{l}\text { Cell } \\
\text { material } \\
\text { formed }(\mathrm{mg})\end{array}$} & \multirow{2}{*}{$\begin{array}{l}\text { Electrons } \\
\text { shunted }^{\mathrm{a}} \\
(\mu \mathrm{mol})\end{array}$} & \multirow{2}{*}{$\begin{array}{l}\text { Electrons } \\
\text { recovered } \\
(\%)\end{array}$} \\
\hline & & & Acetate & Ethanol & Lactate & $\mathbf{H}_{2}$ & & & \\
\hline 0.0 & $<0.005$ & 515.0 & $<10.0$ & $<10.0$ & $<25.0$ & $<3.12$ & $<0.14$ & $<1.00$ & \\
\hline 0.5 & $<0.005$ & 503.0 & $<10.0$ & $<10.0$ & $<25.0$ & $<3.12$ & $<0.14$ & $<1.00$ & 98.0 \\
\hline 5.0 & 0.055 & 464.0 & 41.0 & $<10.0$ & 35.0 & $<3.12$ & 1.54 & 157.00 & 107.0 \\
\hline 9.0 & 0.095 & 341.0 & 92.0 & 53.0 & 38.0 & 15.20 & 2.67 & 495.00 & 106.0 \\
\hline 12.5 & 0.145 & 178.0 & 145.0 & 126.0 & 41.0 & 36.90 & 4.07 & 872.00 & 102.0 \\
\hline 23.0 & 0.190 & $<50.0$ & 204.0 & 162.0 & 53.0 & 50.80 & 5.34 & 1856.00 & 98.7 \\
\hline 53.0 & 0.210 & $<50.0$ & 205.0 & 143.0 & 76.0 & 42.80 & 5.90 & 2317.00 & 106.0 \\
\hline
\end{tabular}

${ }^{a}$ Calculated from integrated current via the equation: $n_{e}=I \times t \times F^{-1}\left(n_{e}=\right.$ amount of electrons; $I=$ current; $t=$ time; $F=$ Faraday constant)

tion experiments with $5 \mathrm{~m} M$ ferrocyanide, a maximum current of only $0.05 \mathrm{~mA}$ was measured, and at twofold mediator concentrations fourfold current outputs were obtained. This problem was overcome by increasing the ionic strength and conductivity of the medium by $0.3 \% \mathrm{NaCl}$ which resulted in a maximum current of $0.6 \mathrm{~mA}$ and a linear correlation between reduced ferrocyanide concentration and current output. Even higher currents were reached by cleaning and activating the working and the counter electrodes by glowing in a flame. As a consequence, maximum currents of $14.0 \mathrm{~mA}$ and $28.0 \mathrm{~mA}$ were obtained with $2.5 \mathrm{~m} M$ and $5.0 \mathrm{~m} M$ ferrocyanide, respectively.

Under these conditions, an electrical current of several milliamperes between working electrode and counter electrode could be recorded during cell growth (Fig. 4a). Cell growth and electron flow were correlated; the electrical current was about proportional to the apparent metabolic activity (growth rate $\times$ cell density). The electron flow was maintained by continuous reoxidation of ferricyanide at the working electrode. The con-

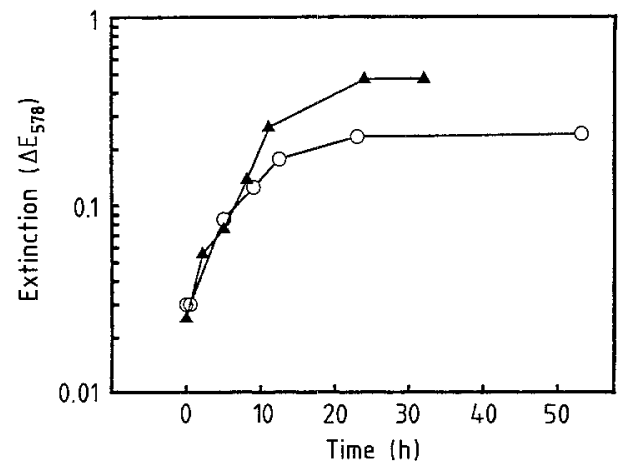

Fig. 5. Growth of $E$. coli with $5 \mathrm{~m} M$ glycerol and $15 \mathrm{~m} M$ fumarate in batch culture (A), and with $5 \mathrm{mM}$ glycerol and $5 \mathrm{~m} M$ potassium ferricyanide in the presence of regulated electrodes (O) 
centration of oxidized mediator remained always high enough to allow glycerol degradation, and glycerol became the growth-limiting factor (Fig. $4 b)$.

As shown in Fig. 4c, the electron potential of the growth medium was kept nearly constant; thus, ferricyanide reoxidation was never the ratelimiting step of glycerol fermentation. Under these conditions, large amounts of electrons (calculated as the integrated current curve) were transferred from the growing bacterial cells to the working electrode. In control experiments without cells or without mediator, no electron transfer occurred. In control experiments without glycerol, only very few electrons from peptone fermentation were transferred. The products of glycerol degradation were the same as in the batch culture experiments (Fig. 4d). Electron balances in the range of $98 \%-107 \%$ were obtained (Table 3). Growth of $E$. coli was exponential, and a growth rate of $0.095 \mathrm{~h}^{-1}$ could be calculated (Fig. 5). This growth rate was lower than the growth rate with fumarate as electron acceptor, measured in batch culture experiments in the presence of $5 \mathrm{~m} M$ glycerol and $15 \mathrm{~m} M$ fumarate $\left(0.212 \mathrm{~h}^{-1}\right)$. Also the growth yield remained lower than in comparable experiments with fumarate.

\section{Discussion}

Potassium ferricyanide was found to be a wellsuited mediator, fulfilling the following postulations listed by Fultz and Durst (1982): (1) welldefined electron stoichiometry ( $n$ value); (2) kown formal potential, $E_{0}^{\prime}$; (3) fast heterogeneous and homogeneous electron transfer; (4) ready solubility in aqueous media at or near pH 7.0; (5) stability in both oxidized and reduced forms; (6) no optical interference with optical monitoring of the biocomponent; and (7) no interaction with the biocomponent in a manner which alters its redox potential.

Because of the polar character of potassium ferricyanide, no uncoupling effect at the bacterial membrane was served. In contrast to many organic mediators which change their redox potential drastically with the prevailing $\mathrm{pH}$ (Prince et al. 1981), no protons are involved in the oxidation-reduction reaction, and the potential remained constant at altering culture conditions. The electron transfer rates obtained from the reoxidation experiments were sufficient to maintain the redox potential of the medium nearly constant during growth of $E$. coli with $5 \mathrm{mM}$ glycerol and $5 \mathrm{~m} M$ potassium ferricyanide. After the equation: $n_{e}=I \times t \times F^{-1}, 37.5 \mu \mathrm{mol}$ electrons $/ \mathrm{h}$ were transferred to the working electrode at a constant current flow of $1 \mathrm{~mA}$.

Surprising results of the batch culture experiments were the incomplete reduction of potassium ferricyanide and the low growth yields obtained. The redox potential of the ferri/ferrocyanide couple $(+430 \mathrm{mV})$ would allow one more phosphorylation reaction than reduction of fumarate by reduced nicotine adenine dinucleotide (NADH) electrons, and therefore higher yields than with fumarate should be expected. However, experiments with $E$. coli and $\mathrm{Fe}^{(\mathrm{III})}$-citrate as electron acceptor (Williams and Poole 1987) indicate that electrons flow from NADH directly to $\mathrm{Fe}^{(\mathrm{III})}$ without participation of membrane-bound electron carriers. Oxidation of glycerol with $\mathrm{Fe}^{(\mathrm{III})}$ would allow only substrate-linked phosphorylation (SLP), whereas fumarate reduction provides electron transport phosphorylation (ETP) as well.

Fermentation of glycerol and fumarate to acetate, ethanol and succinate according to the stoichiometry given in Table 1 (150 umol fumarate) would provide 2.3 ATP per glycerol dissimilated (1.4 ATP via SLP); fermentation to acetate, ethanol, lactate and reduced ferrocyanide according to Table $2(150 \mu \mathrm{mol}$ ferricyanide $)$ yields $1.4 \mathrm{ATP}$ per glycerol, and according to Table 3 (23 h incubation) 1.5 ATP per glycerol via SLP only. The obtained growth yields $(18.4 \mathrm{~g}$ cell material $/ \mathrm{mol}$ glycerol with fumarate versus $10.6 \mathrm{~g} / \mathrm{mol}^{-1}$ with ferricyanide in batch culture, and $11.7 \mathrm{~g} / \mathrm{mol}^{-1}$ with regulated electrodes) correlate exactly with these energy yields and thus corroborate the interpretation that ferricyanide reduction by $E$. coli is not coupled to ETP, confirming the results of Hadjipetrou et al. (1966). With this, E. coli differs basically from other bacteria which reduce iron at sites of the respiratory chain prior to cytochromes b and c (Dailey and Lascelles 1977; Lascelles and Burke 1978) and conserve energy by iron reduction (Balashova and Zavarzin 1980; Lovley and Phillips 1988). It is concluded that $E$. coli can grow and oxidize glycerol anaerobically with ferricyanide as electron acceptor which in turn is reoxidized by a regulated electrode system. Further investigations will clarify if comparable results can be obtained with other fermenting bacteria, even strict anaerobes, and if the end-product pattern in such fermentations can be influenced. First results with propionic acid bacteria look promising. 


\section{References}

Balashova VV, Zavarzin GA (1980) Anaerobic reduction of ferric iron by hydrogen bacteria. Microbiology 48:635639

Bergmeyer HU (1974) Methoden der enzymatischen Analyse, 3rd edn. Verlag Chemie, Weinheim

Dailey HA, Lascelles J (1977) Reduction of iron and synthesis of protoheme by Spirillum itersonii and other organisms. J Bacteriol 129:815-820

Davis G, Hill HOA, Aston WJ, Higgins IJ, Turner APF (1983) Bioelectrochemical fuel cell and sensor based on a quinoprotein, alcohol dehydrogenase. Enzyme Microb Technol $5: 383-388$

Dehning I, Schink B (1989) Malonomonas rubra gen. nov. sp. nov., a microaerotolerant anaerobic bacterium growing by decarboxylation of malonate. Arch Microbiol (in press)

Delaney GM, Bennetto HP, Mason JR, Roller SD, Stirling JL, Thurston CF (1984) Electron-transfer coupling in microbial fuel cells. 2. Performance of fuel cells containing selected microorganisms-mediator-substrate combinations. J Chem Technol Biotechnol 34B:13-27

Fultz ML, Durst RA (1982) Mediator compounds for the electrochemical study of biological redox systems: a compilation. Anal Chim Acta 140:1-18

Hadjipetrou LP, Gray-Young T, Lilly MD (1966) Effect of ferricyanide on energy production by Escherichia coli. J Gen Microbiol 45:479-488

Lang E, Lang H (1972) Spezifische Farbreaktionen zum direkten Nachweis der Ameisensäure. Z Analyt Chem 260:810

Lascelles J, Burke KA (1978) Reduction of ferric iron by Llactate and DL-glycerol-3-phosphate in membrane preparations from Staphylococcus aureus and interactions with the nitrate reductase system. J Bacteriol 134:585-589

Lin ECC (1976) Glycerol dissimilation and its regulation in bacteria. Ann Rev Microbiol 30:535-578

Lovley DR, Phillips EJP (1988) Novel mode of microbial energy metabolism: organic carbon oxidation coupled to dissimilatory reduction of iron or manganese. Appl Environ Microbiol 54:1472-1480

Matthies C, Mayer F, Schink B (1989) Fermentative degradation of putrescine by new strictly anaerobic bacteria. Arch Microbiol (in press)

Metcalfe LD, Schmitz AA, Pelka JR (1966) Rapid preparations of fatty acid esters from lipids for gas chromatographic analysis. Anal Chem 38:514-515
Nishikawa S, Sakai S, Karube I, Matsunaga T, Suzuki S (1982) Dye-coupled electrode systems for the rapid determination of cell populations in polluted water. Appl Environ Microbiol 43:814-818

Pfennig N (1978) Rhodocyclus purpureus gen. nov. and sp. nov., a ring shaped, vitamin $B_{12}$-requiring member of the family Rhodospirillaceae. Int J Syst Bacteriol 28:283-288

Plotkin EV, Higgins IJ, Hill HOA (1981) Methanol dehydrogenase bioelectrochemical cell and alcohol detector. Biotechnol Lett 3:187-192

Prince RC, Linkletter SJG, Dutton PL (1981) The thermodynamic properties of some commonly used oxidation-reduction mediators, inhibitors and dyes, as determined by polarography. Biochim Biophys Acta 635:132-148

Ramsay G, Turner APF, Franklin A, Higgins IJ (1985) Rapid bioelectrochemical methods for the detection of living microorganisms. IFAC Publications:95-101

Roller SD, Bennetto HP, Delaney GM, Mason JR, Stirling JL, Thurston CF (1984) Electron-transfer coupling in microbial fuel cells. 1. Comparison of redox-mediator reduction rates and respiratory rates of bacteria. $J$ Chem Technol Biotechnol 34B:3-12

Tanaka K, Vega CA, Tamaushi R (1983) 612bis-Thionine and ferric chelate compounds as coupled mediators in microbial fuel cells. Bioelectrochem Bioenerg 11:289-297

Turner APF, Aston WJ, Higgins IJ, Davis G \& Hill HOA (1982) Applied aspects of bioelectrochemistry: fuel cells, sensors and bioorganic syntheses. Biotechnol Bioeng Symp 12:401-412

Turner APF, Ramsay G, Higgins IJ (1983) Applications of electron transfer between biological systems and electrodes. Biochem Soc Trans 11:445-448

Widdel F, Kohring GW, Mayer F (1983) Studies on dissimilatory sulfate-reducing bacteria that decompose fatty acids. III. Characterization of the filamentous gliding Desulfonema limicola gen. nov. sp. nov., and Desulfonema magnum sp. nov. Arch Microbiol 134:286-294

Williams HD, Poole RK (1987) Reduction of iron(III) by Escherichia coli K12: lack of involvement of the respiratory chains. Curr Microbiol 15:319-324

Received 9 May 1989/Accepted 14 July 1989 